\title{
MONITORING OF THE ARTIFICIAL REEF FISH ASSEMBLAGES OF GOLFE JUAN MARINE PROTECTED AREA (FRANCE, NORTH-WESTERN MEDITERRANEAN)*
}

\author{
Bodilis Pascaline $^{l^{* *}}$, Seytre Catherine ${ }^{I}$, Eric Charbonnel $^{2}$ and Francour Patrice $^{l}$ \\ ${ }^{1}$ University of Nice Sophia Antipolis, Faculty of Sciences \\ ECOMERS Laboratory \\ (Parc Valrose, 06108 Nice Cedex 02, France) \\ ${ }^{2}$ Parc Marin de la Côte Bleue, Observatoire, plage du Rouet \\ (BP 42, 13 620 Carry-le-Rouet, France) \\ **Corresponding author: pascaline.bodilis@unice.fr
}

\section{A B S T R A C T}

Artificial reefs were deployed within the Golfe-Juan marine protected area (Alpes-Maritimes coast, France, Northwestern Mediterranean) created in 1981. This no-take area is fully protected since its establishment, except in 2004 when some anthropic activities were, exceptionally, authorized. Moreover, no park rangers to prevent poaching since 2002 occur. In order to carry out a long term monitoring of the artificial reef fish assemblages, underwater visual censuses (UVC) were carried out in 1988, 1998 and 2008, according to a traditional standardized visual census method that taken into account all fish species. The complexification of some large reefs built with wide voide spaces called Bonna reefs appear to be a good solution to increase species richness and density. Species richness and density of the fish assemblages showed significant increase between 1988 and 1998 . However the fast increasing was stopped from 1998 and 2008 probably due to a lack of law enforcement and poaching. Despite artificial reefs were deployed in MPA since at least 20 years, they did not show a real positive impact on fish assemblages. These results could be explained (i) by a lack of law enforcement patrol within the protected areas during the last decade, and (ii) by the one-year opening to fishing activities within MPA. The real effectiveness of the artificial reefs in sustaining fish assemblages is discussed and the necessity of a regular and efficient control by park rangers is highlighted.

\section{RESUMO}

Recifes artificiais foram implantados na área protegida Golfe-Juan (costa dos Alpes-Maritimes, Noroeste do Mediterraneo) criada em 1981. Esta área NTZ (Area de Restrição da Pesca ) é inteiramente protegida, desde seu estabelecimento, exceto em 2004, quando algumas atividades antropicas foram excepcionalmente autorizadas. Além disso, desde 2002, não houve nenhuma patrulha florestal para impedir a caça e pesca ilegais. . A fim realizar um monitoramento a longo prazo das assembléias artificiais dos peixes do recife, recenseamentos visuais subaquáticos (UVC) foram realizados em 1988, 1998 e 2008, de acordo com um método visual tradicional de recenseamento, que leva em consideração todas as espécies de peixes. A complexidade de alguns recifes grandes, construídos com amplos espaços vagos, chamados recifes Bonna parece ser uma boa solução para aumentar a riqueza e a densidade das espécies. A riqueza das espécies e a densidade das assembléias de peixes mostraram um aumento significativo entre 1988 e 1998. Entretanto esse aumento rápido parou entre 1998 e 2008 provavelmente devido à falta da aplicação da lei contra a caça e pesca ilegal. . Apesar dos recifes artificiais terem sido instalados em MPAs pelo menos há 20 anos atrás, eles não apresentaram um impacto positivo real nas assembléias de peixes. Estes resultados podem ser explicados (i) por uma falta de patrulhamento da aplicação da lei dentro das áreas protegidas durante a última década, e (ii) pela abertura de um ano de atividades de pesca dentro das MPAs. A eficiência real dos recifes artificiais para sustentar assembléias de peixes é discutida, destacando-se a necessidade de um controle regular e de um patrulhamento regular e eficiente dos parques.

Descriptors: Artificial reefs, Mediterranean sea, Fish assemblages, MPAs, UVC, Monitoring, Reefs performance.

Descritores: Recifes artificiais, Mar Mediterrâneo, Assembléias de peixes, MPAs, UVC, Monitoramento, Desempenho recifes. 


\section{INTRODUCTION}

An artificial reef consists of one or more objects of natural or human origin deployed purposefully on the sea-floor to influence physical, biological or socioeconomic processes related to living marine resources (SEAMAN; JENSEN, 2000). Artificial reefs can be submerged for the purposes of (BRICKHILL et al., 2005): increasing fishing resources and mitigating environmental impacts (POLOVINA; SAKAI, 1989; REED et al., 2006); constituting protection for "nurseries" against illegal trawling (CHARBONNEL; FRANCOUR, 1994; GOMEZ-BUCKLEY; HAROUN, 1994; SANTAELLA; REVENGA, 1995; LÖK et al., 2002); enforcing "no fishing" legislation with anti-trawling reefs (FRANCOUR et al., 1991; RAMOS-ESPLA et al., 2000; MORENO, 2002); increasing biodiversity (JENSEN; COLLINS, 1995); promoting the survival of some species (JENSEN et al., 2000), and promoting recreational activities, notably SCUBA diving and angling (BRANDEN et al., 1994). Japan was one of the first countries to use large-scale artificial reefs in order to restore fishery resources. Three hundred and fifty types of reef have been deployed to attract different species and they have protected and attracted millions of crustaceans and fish. The largest reefs are several thousand cubic meters in volume and up to 80 m high (SIMARD, 1995).

Understanding the effectiveness of artificial reefs in increasing fishery resources requires a regular monitoring of the fish assemblages living in and around artificial reefs. Fish assemblage censuses can be undertaken using destructive methods such as trawling (BOMBACE et al., 1994), or non-destructive methods such as the underwater visual census (BAYLE-SEMPERE et al., 1994; CHARBONNEL; FRANCOUR, 1994; CHARBONNEL et al., 1997; BORTONE et al., 2000; SANTOS; MONTEIRO, 2007). When artificial reefs are deployed in marine protected areas, non-destructive methods are preferred (CHARBONNEL et al., 1997).

A decrease has been observed in the Posidonia oceanica seagrass beds and fishery resources following the urbanization of the AlpesMaritimes coastline (Northwestern Mediterranean sea) (MEINESZ et al., 1985). As a consequence marine protected areas (MPAs) were created in the department in accordance with a decision taken by professional fishermen to increase fishery resources. The local government (the Conseil Général des AlpesMaritimes) created three MPAs at the beginning of the 80 s with the agreement of the professional fishermen. These areas were set up along the coast off the cities of Golfe-Juan, Beaulieu-sur-Mer and RoquebruneCap-Martin. Our study focuses on the Golfe-Juan
MPA, created in 1981 , a protected area of 50 ha in which $7970 \mathrm{~m}^{3}$ of reefs were deployed on a muddy and sandy bottom at depths of between 27 and $36 \mathrm{~m}$ (CHARBONNEL, 1990; CHARBONNEL; SERRE, 1999). This MPA is in theory a no-take area. All anthropic activities are forbidden: angling, anchoring, SCUBA diving and all sorts of fishing. However, some administrative difficulties led to a reopening of the MPA during the whole of 2004 and some anthropic activities (fishing, angling) were authorized inside the MPA throughout the year. Moreover, since 2002, the lack of any surveillance inside the MPA has allowed poaching to occur and, in consequence, professional and non-professional fishing activities are regularly to be observed within the MPA.

In order to evaluate the effectiveness of these artificial reefs after 30 years of immersion we compared censuses undertaken in 1988, a few years after the creation of the MPA, in 1998 and in 2008. We then tested the hypothesis that fish abundances had increased from 1988 to 2008 .

\section{Methods}

\section{Study Area}

The MPA studied is situated off the city of Golfe-Juan (Var, Northwestern Mediterranean, France) (Fig. 1). Several types of reefs of various sizes, hereafter called stations, were deployed in the area between 1981 and 1988 (CHARBONNEL, 1990). Censuses of the 7 most representative stations were undertaken (Table 1). The smallest reef units consist of concrete cubes (of $1 \mathrm{~m}^{3}$ ) or parallelepipeds (of 2 $\mathrm{m}^{3}$ ) with large holes in them. These small units were disposed randomly on the bed of the MPA. The biggest reefs $\left(158 \mathrm{~m}^{3}\right)$, called Bonna reefs, consist of nine perforated concrete slabs with wide empty spaces and were created to attract pelagic fish species. Some Bonna reefs were complexified in 1989, after the first survey. Complexification consists of adding small elements (concrete bricks, tires, pieces of reef) within the Bonna reefs in order to create numerous holes of different sizes (CHARBONNEL et al. 2002). A natural rocky area was sampled, as a control site, during the same period.

\section{Data Collection}

Data were collected during three seasons (cold, intermediate and warm) in each of the years 1988, 2000 and 2008. The cold season lasts from November to March (mean water temperature ca. $13^{\circ} \mathrm{C}$ ), the intermediate season from April to June (mean water temperature ca. $16^{\circ} \mathrm{C}$ ) and the warm 
season from July to October (mean water temperature ca. $20^{\circ} \mathrm{C}$ ). Data were collected by SCUBA divers using a standardized underwater visual census method (BORTONE et al., 2000). At each station two divers undertook the census of the reef or group of reef units at the same time: each diver moving in the opposite direction to the other diver to avoid disturbing the fish fauna. All individuals were counted. Three size classes, defined in terms of thirds of each species' maximum length (small: $<1 / 3 \mathrm{TL}$; medium: $1 / 3$ to $2 / 3 \mathrm{TL}$; large: $>2 / 3 \mathrm{TL}$ ) were recorded. Fish Base data maximum TL was used. A census was undertaken at each station at least three times during each season. All reefs were small enough to allow total populations to be assessed without subsampling or extrapolation.

\section{Statistical analysis}

Species richness (mean number of species per $100 \mathrm{~m}^{3}$ ) and density (mean number of individuals per $\mathrm{m}^{3}$ ) were calculated from data of abundance collected during sampling. Density was calculated for all the species, except planktonophagous species (Boops boops, Chromis chromis, Oblada melanura and Spicara sp.) that can mask trends due to high variance in UVC data (CHARBONNEL, 1990). For the natural area, the density of fish assemblage has been expressed by cubic metre, as for the artificial reef fish assemblages, considering that the divers undertook the censuses of the fish on the basis of a $1.25 \times 50$ (width $\times$ length) $\times 1 \mathrm{~m}$ (height above the substrate) volume (Table 1 ).

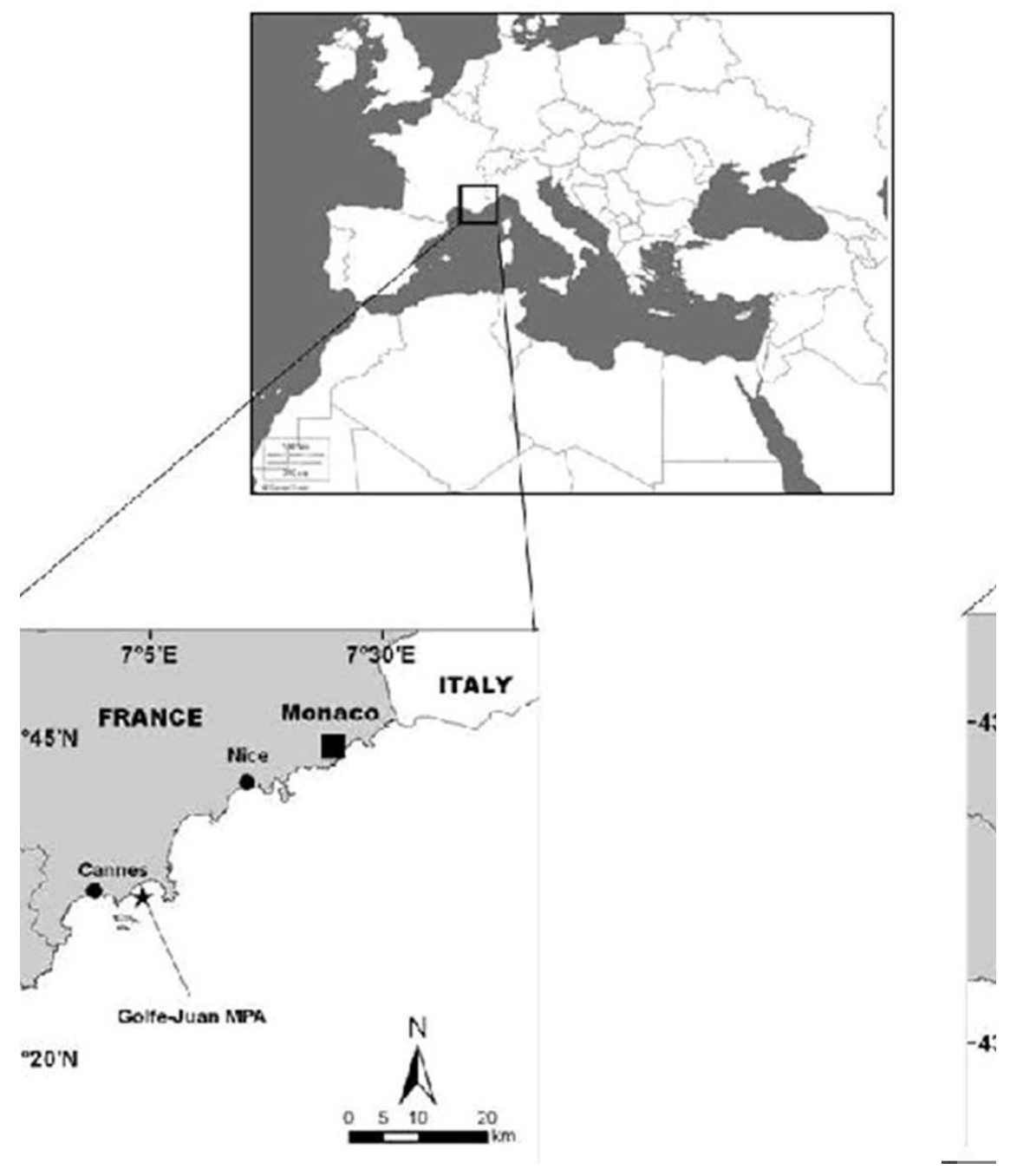

Fig. 1. Localisation of the Golfe-Juan MPA (Northwestern Mediterranean Sea, France). 
Table 1. Summary of the parameters of the different sampling stations.

\begin{tabular}{|c|c|c|c|c|c|}
\hline Station & Design & Dimensions of one unit (m) & Number of units & Bulk volume $\left(\mathrm{m}^{3}\right)$ & Depth (m) \\
\hline GJ1 & $1 \mathrm{~m}^{3}$ units spread out & $1 \times 1 \times 1$ & 500 & 500 & 30 \\
\hline GJ3 & $\begin{array}{l}1 \mathrm{~m}^{3} \text { units in chaotic shape } \\
\text { add to } 4 \text { closed alveolar reefs }\end{array}$ & $1 \times 1 \times 1+0.9 \times 1.7 \times 1.25$ & $80+4$ & 112 & 30 \\
\hline GJ4 & $2 \mathrm{~m}^{3}$ in a chaotic shape & $0.9 \times 1.7 \times 1.25$ & 36 & 72 & 30 \\
\hline GJ5 & $2 \mathrm{~m}^{3}$ in a chaotic shape & $0.9 \times 1.7 \times 1.25$ & 36 & 72 & 30 \\
\hline GJ6 & Empty Bonna reef & $6 \times 6 \times 4.4$ & 1 & 158 & 28 \\
\hline GJ7 & Complexified Bonna reef & $6 \times 6 \times 4.4$ & 1 & $158+40$ & 27 \\
\hline GJ8 & Natural area: rocky area & $1.5 \times 50 \times 1$ & & 75 & 32 \\
\hline
\end{tabular}

Permutational MANOVA (PERMANOVA) were undertaken to compare the change in species richness and density of the fish assemblages as between years sampled. Pairwise-tests allowed each type of reef to be compared as between years. A BrayCurtis similarity test was applied to square-root transformed data.

A MDS, using Bray-Curtis similarity indices, was undertaken on density estimates per species for each year, and an analysis of similarity percentages (SIMPER) was used to examine potential differences in fish assemblage structure among sites. Primer 6 software was used to perform all these tests. PERMANOVA + package for PRIMER 6 software (CLARK; WARWICK, 2001; ANDERSON; GORLEY, 2007) was used to carry out the PERMANOVA.

\section{RESUlts}

Sixty-one species belonging to 22 families were observed during the three survey periods (Table 2). Forty-eight species were observed in 1988, 49 in 1998 and 51 in 2008. Whatever the period, the two main families observed were Labridae and Sparidae (46\% in 88, $42 \%$ in 98 and $40 \%$ of the total number of species in 2008). Gobiidae were the third most important family: 4 species were observed in 1988, 4 in 1998 and 9 in 2008. Serranidae and Scorpaenidae, two families of commercial value, were represented respectively by 5 and 3 species. Blenniidae, Carangidae, Centracanthidae, Gadidae each accounted for two or three species. Only one species of the 16 remaining families was observed. One species (rarely observed) was only identified in 2008: a Gobiidae, Corcyrogobius liechtensteini.

The PERMANOVA applied to species richness and density data revealed significant differences for the factors "reef" and "year" and for the interaction "reef $\mathrm{x}$ year" (Table 3). PERMANOVA pair-wise comparison results showed significant differences between the year 1988 and the other two. No significant differences were observed as between the years 1988 and 2008 for any of the areas. Pair-wise comparisons revealed no significant differences for empty Bonna reefs during the three survey periods. On the other hand, species richness and density of the complexified Bonna reefs differ significantly between years. Moreover these comparisons revealed that most reef types do not differ significantly between years.

The evolution of species richness and density for all reef types during the three survey periods confirm these results (Fig. 2; p > 0.05). Comparing natural areas and artificial reefs, species richness of $2 \mathrm{~m}^{3}$ reefs and natural areas evolved in the same way regardless of the year studied and showed the highest richness. Density results modify this fact for artificial reefs. Only density in natural areas is higher for all the three years than it is on artificial reefs (Fig. 2; $p<0.05$ ).

Complexified Bonna reefs only showed significant differences for density data from empty Bonna reefs in 1998 (Fig. 2; p < 0.05). But an important increase in density on complexified Bonna reefs was observed from 1988 to 1998 (Fig. 2). This result is supported by the significant differences observed between these two years for complexified Bonna reefs in PERMANOVA pair-wise comparisons (Table 3).

The main result of the multidimensional scaling (MDS) was that both empty Bonna and complexified Bonna reefs in 1988 (i.e. before their complexification in 1989) were seen to be clearly distinct from the other artificial reef types and natural areas (Fig. 3). In addition, the $1 \mathrm{~m}^{3}$ and $2 \mathrm{~m}^{3}$ reefs were grouped together whatever the year.

The differences highlighted by the PERMANOVA and MDS between 1998 and the two other years are mainly due to the high densities of Diplodus spp. in 1998 as compared to their low densities in 1988 and 2008, whatever the reefs (Table 4a). The year 1988 was also marked by the higher density of Boops boops than in 1998 and 2008. The differences between the empty Bonna reefs and the other stations were still due to low densities of Diplodus spp., Apogon imberbis and Anthias anthias on the empty Bonna reefs. 
Table 2. List of species censussed from 1988 to 2008 (*: presence of the species; C: commercial species).

\begin{tabular}{|c|c|c|c|c|c|c|c|c|c|c|}
\hline Family & Species & 1988 & 1998 & 2008 & Family & Species & 1988 & 1998 & 2008 & \\
\hline Apogonidae & $\begin{array}{l}\text { Apogon imberbis (Linnaeus, } \\
1758 \text { ) }\end{array}$ & $*$ & $*$ & $*$ & Moronidae & Dicentrarchus labrax & & & $*$ & $\mathrm{C}$ \\
\hline \multirow[t]{2}{*}{ Blenniidae } & $\begin{array}{l}\text { Parablennius gattorugine } \\
\text { (Linnaeus, 1758) }\end{array}$ & $*$ & $*$ & $*$ & Lophiidae & $\begin{array}{l}\text { Lophius piscatorius Linnaeus, } \\
1758\end{array}$ & & $*$ & & $\mathrm{C}$ \\
\hline & $\begin{array}{l}\text { Parablennius rouxi (Cocco, } \\
1833)\end{array}$ & $*$ & $*$ & $*$ & Mugilidae & Mugil sp. & $*$ & $*$ & & \\
\hline Carangidae & Seriola dumerili (Risso, 1810) & $*$ & & & Mullidae & $\begin{array}{l}\text { Mullus surmuletus Linnaeus, } \\
1758\end{array}$ & $*$ & $*$ & $*$ & $\mathrm{C}$ \\
\hline \multirow[t]{2}{*}{ Centracanthidae } & Spicara maena (Linnaeus, 1758) & $*$ & $*$ & $*$ & Muraenidae & Muraena helena Linnaeus, 1758 & $*$ & $*$ & $*$ & \\
\hline & Spicara smaris (Linnaeus, 1758) & $*$ & $*$ & $*$ & Pomacentridae & $\begin{array}{l}\text { Chromis chromis Linnaeus, } \\
1758\end{array}$ & $*$ & $*$ & $*$ & \\
\hline Congridae & Conger conger Linnaeus, 1758 & $*$ & $*$ & $*$ & C Sciaenidae & Sciaena umbra Linnaeus, 1758 & & $*$ & $*$ & \\
\hline Dasyatidae & Dasyatis sp. & & $*$ & & Scorpaenidae & $\begin{array}{l}\text { Scorpaena notata Rafinesque, } \\
1810\end{array}$ & $*$ & $*$ & $*$ & $\mathrm{C}$ \\
\hline \multirow[t]{2}{*}{ Gadidae } & Phycis phycis (Linnaeus, 1766) & $*$ & $*$ & $*$ & $\mathrm{C}$ & $\begin{array}{l}\text { Scorpaena porcus Linnaeus, } \\
1758\end{array}$ & $*$ & $*$ & $*$ & $\mathrm{C}$ \\
\hline & $\begin{array}{l}\text { Trisopterus minutus (Linnaeus, } \\
\text { 1758) }\end{array}$ & $*$ & & & & $\begin{array}{l}\text { Scorpaena scrofa Linnaeus, } \\
1758\end{array}$ & $*$ & $*$ & $*$ & $\mathrm{C}$ \\
\hline \multirow[t]{10}{*}{ Gobiidae } & Aphia minuta (Risso, 1810) & & $*$ & & Serranidae & $\begin{array}{l}\text { Anthias anthias (Linnaeus, } \\
1758 \text { ) }\end{array}$ & $*$ & $*$ & $*$ & \\
\hline & $\begin{array}{l}\text { Corcyrogobius liechtensteini } \\
\text { (Kolombatovic, 1891) }\end{array}$ & & & $*$ & & $\begin{array}{l}\text { Epinephelus marginatus (Lowe, } \\
\text { 1834) }\end{array}$ & & $*$ & $*$ & \\
\hline & Gobius auratus Risso, 1810 & $*$ & $*$ & $*$ & & $\begin{array}{l}\text { Serranus cabrilla (Linnaeus, } \\
\text { 1758) }\end{array}$ & $*$ & $*$ & $*$ & $\mathrm{C}$ \\
\hline & Gobius cruentatus Gmelin, 1789 & $*$ & & $*$ & & $\begin{array}{l}\text { Serranus hepatus (Linnaeus, } \\
1758 \text { ) }\end{array}$ & $*$ & & & \\
\hline & $\begin{array}{l}\text { Gobius geniporus Valenciennes, } \\
1837\end{array}$ & & $*$ & $*$ & & $\begin{array}{l}\text { Serranus scriba (Linnaeus, } \\
1758 \text { ) }\end{array}$ & $*$ & & $*$ & $\mathrm{C}$ \\
\hline & $\begin{array}{l}\text { Gobius paganellus Linnaeus, } \\
1758\end{array}$ & & & $*$ & Sparidae & Boops boops (Linnaeus, 1758) & $*$ & $*$ & $*$ & $\mathrm{C}$ \\
\hline & $\begin{array}{l}\text { Gobius xanthocephalus Heymer } \\
\text { \& Zander, } 1992\end{array}$ & $*$ & $*$ & $*$ & & Dentex dentex (Linnaeus, 1758) & $*$ & $*$ & $*$ & $\mathrm{C}$ \\
\hline & Pomatoschistus sp. & & & $*$ & & $\begin{array}{l}\text { Diplodus annularis (Linnaeus, } \\
1758 \text { ) }\end{array}$ & $*$ & $*$ & $*$ & $\mathrm{C}$ \\
\hline & $\begin{array}{l}\text { Thorogobius ephippiatus (Lowe, } \\
\text { 1839) }\end{array}$ & $*$ & $*$ & $*$ & & Diplodus puntazzo (Cetti, 1777) & $*$ & $*$ & $*$ & $\mathrm{C}$ \\
\hline & $\begin{array}{l}\text { Thorogobius macrolepis } \\
\text { (Kolombatovic, 1891) }\end{array}$ & & & $*$ & & $\begin{array}{l}\text { Diplodus sargus (Linnaeus, } \\
1758 \text { ) }\end{array}$ & $*$ & $*$ & $*$ & $\mathrm{C}$ \\
\hline \multirow[t]{11}{*}{ Labridae } & Coris julis (Linnaeus, 1758) & $*$ & $*$ & $*$ & & $\begin{array}{l}\text { Diplodus vulgaris (Geoffroy } \\
\text { Saint-Hilaire, 1817) }\end{array}$ & $*$ & $*$ & $*$ & $\mathrm{C}$ \\
\hline & Labrus merula Linnaeus, 1758 & $*$ & $*$ & $*$ & $\mathrm{C}$ & $\begin{array}{l}\text { Oblada melanura (Linnaeus, } \\
1758 \text { ) }\end{array}$ & $*$ & $*$ & $*$ & $\mathrm{C}$ \\
\hline & Labrus mixtus Linnaeus, 1758 & $*$ & $*$ & & & $\begin{array}{l}\text { Pagellus erythrinus (Linnaeus, } \\
1758 \text { ) }\end{array}$ & $*$ & & & $\mathrm{C}$ \\
\hline & Labrus viridis Linnaeus, 1758 & $*$ & $*$ & $*$ & $\mathrm{C}$ & Pagrus pagrus (Linnaeus, 1758) & $*$ & $*$ & & $\mathrm{C}$ \\
\hline & $\begin{array}{l}\text { Symphodus cinereus (Bonaterre, } \\
1788 \text { ) }\end{array}$ & $*$ & $*$ & $*$ & & Sarpa salpa (Linnaeus, 1758) & $*$ & & $*$ & $\mathrm{C}$ \\
\hline & $\begin{array}{l}\text { Symphodus doderleini Jordan, } \\
1890\end{array}$ & $*$ & $*$ & $*$ & & Sparus aurata Linnaeus, 1758 & $*$ & $*$ & $*$ & $\mathrm{C}$ \\
\hline & $\begin{array}{l}\text { Symphodus mediterraneus } \\
\text { (Linnaeus, 1758) }\end{array}$ & $*$ & $*$ & $*$ & & $\begin{array}{l}\text { Spondyliosoma cantharus } \\
\text { (Linnaeus, 1758) }\end{array}$ & $*$ & $*$ & $*$ & $\mathrm{C}$ \\
\hline & $\begin{array}{l}\text { Symphodus melanocercus (Risso, } \\
1810 \text { ) }\end{array}$ & $*$ & $*$ & $*$ & Sphyraenidae & $\begin{array}{l}\text { Sphyraena viridensis Cuvier, } \\
1829\end{array}$ & & $*$ & $*$ & $\mathrm{C}$ \\
\hline & $\begin{array}{l}\text { Sympodus ocellatus (Forsskål, } \\
1775 \text { ) }\end{array}$ & $*$ & $*$ & $*$ & Torpedinidae & $\begin{array}{l}\text { Torpedo marmorata Risso, } \\
1810\end{array}$ & & $*$ & $*$ & \\
\hline & $\begin{array}{l}\text { Symphodus rostratus (Bloch, } \\
1791 \text { ) }\end{array}$ & $*$ & $*$ & $*$ & Tripterygiidae & $\begin{array}{l}\text { Tripterygion delaisi Cadenat \& } \\
\text { Blache, } 1971\end{array}$ & $*$ & $*$ & $*$ & \\
\hline & $\begin{array}{l}\text { Symphodus tinca (Linnaeus, } \\
1758 \text { ) }\end{array}$ & $*$ & $*$ & $*$ & $\mathrm{C} \begin{array}{l}\text { Number of } \\
\text { species }\end{array}$ & 61 & 48 & 49 & 51 & 26 \\
\hline
\end{tabular}


Table 3. Results of univariate analysis applied on species richness and total density data: permutational MANOVA (a: Main test; b: Pair-wise tests) (ns: not significant; *p < 0.05; **p < 0.01; ***p < 0.001) (RS: species richness; CB: complexified Bonna reefs, EB: Empty Bonna reefs, NA: Natural areas).

\begin{tabular}{|c|c|c|c|c|c|c|c|c|}
\hline RS & $\mathrm{Re}$ & 4 & 24,599 & $5,15043,739$ & $0.000 * * *$ & & & \\
\hline \multirow{9}{*}{ Density } & $\mathrm{Ye}$ & 2 & 4,398 & $2,19915,640$ & $0.000 * * *$ & & & \\
\hline & $\operatorname{Re} x Y e$ & 8 & 15,391 & $1,92413,684$ & $0.000 * * *$ & & & \\
\hline & Res & 223 & 331,3540 , & \multirow[t]{2}{*}{0,141} & & & & \\
\hline & Total & 237 & 775,266 & & & & & \\
\hline & $\mathrm{Re}$ & 4 & 24,328 & $6,08221,149$ & $0.000 * * *$ & & & \\
\hline & $\mathrm{Ye}$ & 2 & 4,505 & $2,2537,833$ & $0.001 * * *$ & & & \\
\hline & Re xYe & 8 & 8,945 & $1,1183,888$ & $0.001 * * *$ & & & \\
\hline & Res & 223 & $364,131 \quad 0$ & 0,288 & & & & \\
\hline & Total & 237 & 7102,920 & & & & & \\
\hline \multicolumn{9}{|l|}{ b } \\
\hline & \multicolumn{2}{|l|}{ Groups } & Whole areas & $1 \mathrm{~m}^{3}$ & $2 \mathrm{~m}^{3}$ & $\mathrm{CB}$ & EB & NA \\
\hline \multirow[t]{3}{*}{ RS } & \multicolumn{2}{|c|}{1998,2008} & 0.075 (ns) & 0.245 (ns) & $0.085(\mathrm{~ns})$ & $0.000 * * *$ & $0.157(\mathrm{~ns})$ & $0.355(\mathrm{~ns})$ \\
\hline & \multicolumn{2}{|c|}{1998,1988} & $0.000 * * *$ & 0.267 (ns) & $0.002 * *$ & $0.000 * * *$ & $0.509(\mathrm{~ns})$ & $0.418(\mathrm{~ns})$ \\
\hline & \multicolumn{2}{|c|}{2008,1988} & $0.000 * * *$ & $0.021^{*}$ & 0.051 (ns) & $0.000^{* * * *}$ & $0.408(\mathrm{~ns})$ & $0.694(\mathrm{~ns})$ \\
\hline \multirow[t]{3}{*}{ Density } & \multicolumn{2}{|c|}{1998,2008} & 0.388 (ns) & $0.526(\mathrm{~ns})$ & $0.111(\mathrm{~ns})$ & $0.006 * *$ & 0.297 (ns) & $0.101(\mathrm{~ns})$ \\
\hline & \multicolumn{2}{|c|}{1998,1988} & $0.001 * * *$ & 0.644 (ns) & 0.055 (ns) & $0.000 * * *$ & $0.204(\mathrm{~ns})$ & $0.911(\mathrm{~ns})$ \\
\hline & \multicolumn{2}{|c|}{2008,1988} & $0.001 * * *$ & 0.635 (ns) & $0.482(\mathrm{~ns})$ & $0.000 * * *$ & $0.379(\mathrm{~ns})$ & $0.027 *$ \\
\hline
\end{tabular}
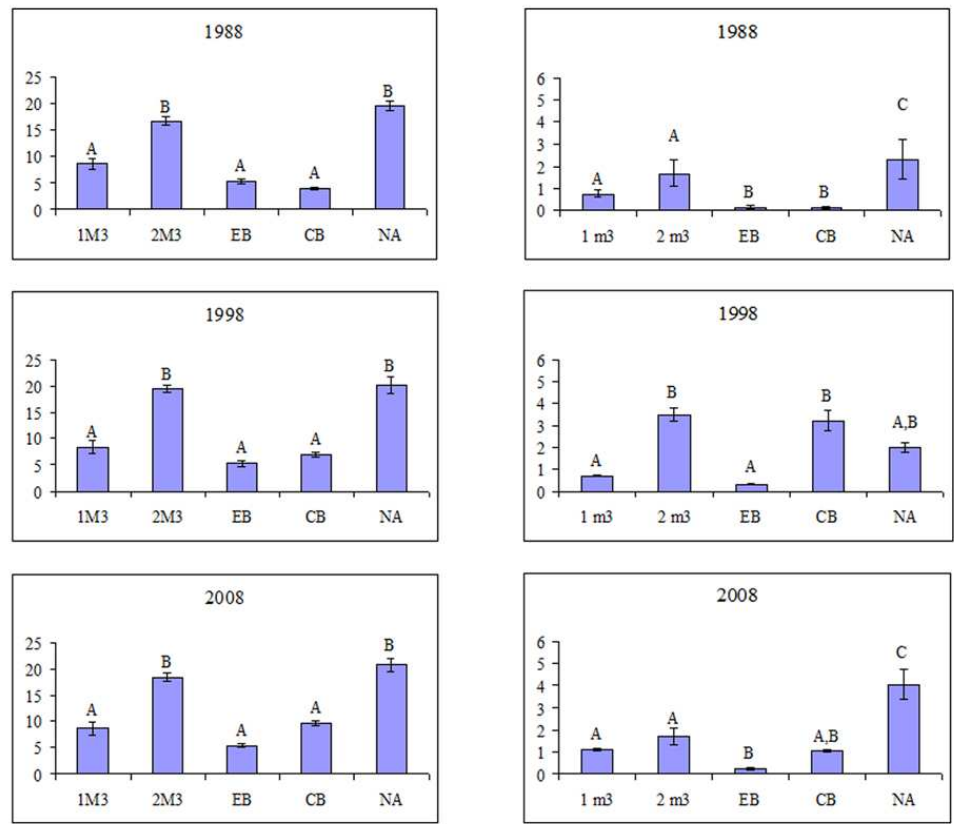

Species richness

Density

Fig. 2. Species richness (left; mean number of species per $\mathrm{m}^{3}$ ) and density (right; mean number of individuals per $\left.\mathrm{m}^{3}\right) \forall$ SE observed during each year of census and during the whole period for the different types of reef studied. Means with differing letters are statistically different $(\mathrm{P}<0.05$, Multiple rank test). EB: empty Bonna; CB: complexified Bonna (previously empty Bonna, complexified in 1989, i.e. after the first sampled period); NA: natural area. 


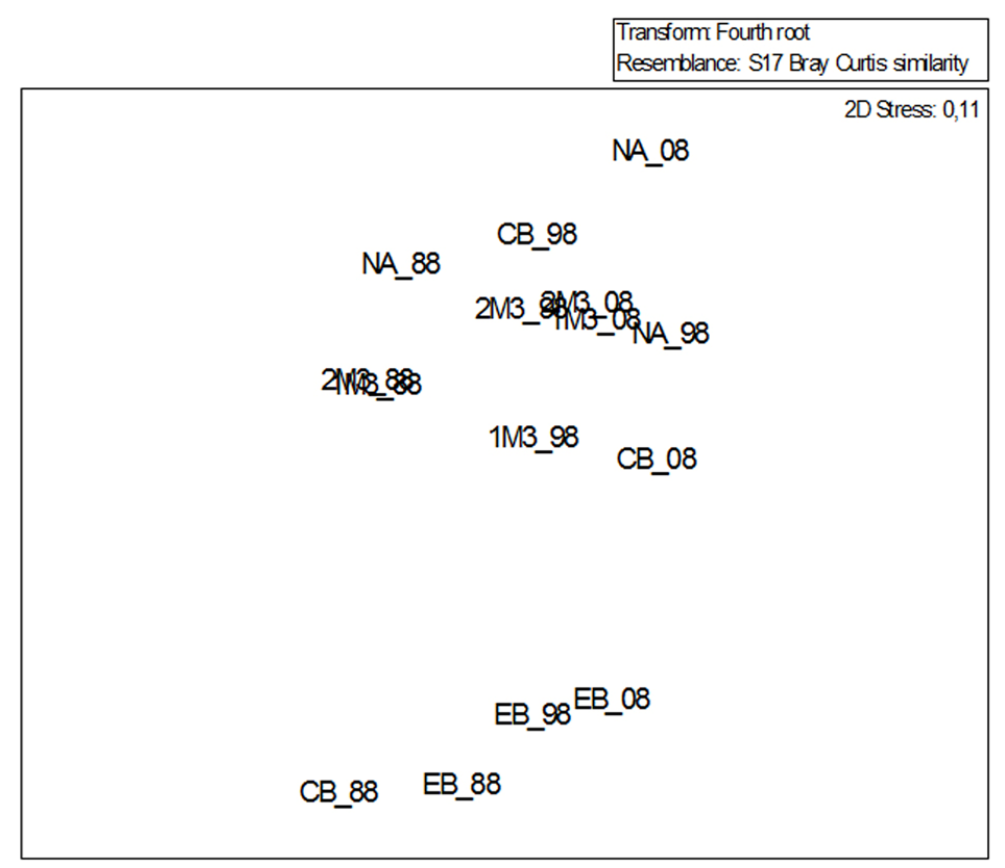

Fig. 3. MDS plots of Bray-Curtis similarity indices of different reefs submerged in the Golfe-Juan MPA. ( $1 \mathrm{M} 3=1 \mathrm{~m}^{3}$ reef; $2 \mathrm{M} 3=2 \mathrm{~m}^{3}$ reefs, $\mathrm{EB}=$ empty Bonna reef, $\mathrm{CB}=$ complexified Bonna reef, NA = natural area; 88,98 , 08: year of sampling).

Table 4. SIMPER percentages of the three species contributing the most to the differences between (a) years and (b) the empty Bonna reefs and all the other stations (artificial reefs and natural areas).

a

\begin{tabular}{|c|c|c|c|c|}
\hline Year & Average dissimilarity & Species name & Dissimilarity (\%) & Cumulative dissimilarity (\%) \\
\hline \multirow[t]{3}{*}{$1988 / 1998$} & 49,99 & Diplodus sargus & 17,40 & 17,40 \\
\hline & & Diplodus vulgaris & 8,78 & 26,18 \\
\hline & & Parablennius rouxi & 6,02 & 32,20 \\
\hline \multirow[t]{3}{*}{$1998 / 2008$} & 44,07 & Diplodus sargus & 16,94 & 16,94 \\
\hline & & Apogon imberbis & 10,52 & 27,46 \\
\hline & & Anthias anthias & 8,42 & 35,88 \\
\hline \multirow[t]{3}{*}{$1988 / 2008$} & 53,67 & Apogon imberbis & 10,86 & 10,86 \\
\hline & & Anthias anthias & 8,13 & 18,98 \\
\hline & & Parablennius rouxi & 7,60 & 26,58 \\
\hline
\end{tabular}

b

$\overline{\text { Year }} \overline{\text { Average dissimilarity }} \overline{\text { Species name }} \overline{\text { Dissimilarity (\%) }} \overline{\text { Cumulative dissimilarity (\%) }}$

198851,55

13,53

Diplodus sargus $\quad 11,17 \quad 24,69$

Coris julis $\quad 11,12 \quad 35,81$

Apogon imberbis $\quad 7,40 \quad 31,53$

Parablennius rouxi $6,25 \quad 37,77$

2008 53,99 Apogon imberbis $\quad 16,20 \quad 16,20$

Anthias anthias $\quad 11,88 \quad 28,08$

Coris julis $\quad 9,74 \quad 37,82$




\section{Discussion}

The main objective of this study was to assess the effectiveness of the different artificial reef types deployed in the MPA surveyed. The fish assemblages were dominated by two main families, Sparidae and Labridae, as it is usually the case on Mediterranean artificial reefs (CHARBONNEL et al., 2002; RELINI et al., 2007) and in natural areas, on rocky substratum (HARMELIN, 1987). The study of the 20 years of monitoring revealed that $2 \mathrm{~m}^{3}$ reefs appeared to have the same level of species richness as natural areas. The important complexity of $2 \mathrm{~m}^{3}$ reefs built haphazardly might explain these results (BOHNSACK, 1989). This observation is confirmed by the very low values obtained for empty Bonna reefs. MDS results showed mainly that empty Bonna reefs and complexified Bonna reefs in 1988 (i.e. before their complexification in 1989) were clearly distinct from the other reefs and natural areas. However, the density on $2 \mathrm{~m}^{3}$ reefs only attained the same level as the natural area in 1998. The increased complexity of the habitats offered by the artificial reefs could attract the fish from neighboring natural areas to artificial reefs. This assumption (migration or displacement) has been frequently opposed to the production hypothesis to explain the increase in density in artificial fields (BOHNSACK, 1989; OSENBERG et al., 2002).

PERMANOVA results showed that considering all reef types the data of the first survey period are closer to those of the last year than to those of the intermediate survey period. These results corroborate the fact that reef performance decreased in the last year as compared to 1998. This decrease could be explained by the opening of the reserve to some anthropic activities in 2004 or by the lack of surveillance within the reserve after 2002. Since 2002 there has been no enforcement of anti-poaching laws and some anthropic activities (fishing, angling, anchoring) were authorized during the whole of 2004 . The impact of fishing in 2004 can only be guessed at as no information about fishing effort is available. However, that there was such an impact is evidenced by the decrease of density in 2008 on the complexified Bonna and $2 \mathrm{~m}^{3}$ reefs and by the non-significant difference observed between 1988 and 2008 in the PERMANOVA results. The higher density observed in the natural area opposite the artificial reefs in 2008 could be due to a "refuge effect" as supposed by Ody and Harmelin (1994).

The complexification of empty Bonna reefs in 1989, just one year after the first monitoring, yielded an important increase in fish density. The process of complexification could be interpreted as the building of a new artificial reef. The sharp decrease of fish density in 2008 after the one-year reopening could then be linked to an increase of non-professional fishing activity (angling). As observed in a previous study the empty Bonna reefs are ineffective (CHARBONNEL et al. 2000). The advantage of complexified reefs as a means of increasing the number of individuals is confirmed by the comparison of the evolution of species richness and density on both the complexified and empty Bonna reefs. Density increased sharply after the complexification. Moreover, the results of SIMPER analysis revealed great dissimilarities in the species composition between the empty and complexified Bonna reefs even though species richness does not really differ as between the two types of Bonna reefs. These observations confirm the results obtained in a previous study as to the advantage of complexified reefs (CHARBONNEL et al., 2002). But the rapid increase observed over the first ten years seemed to come to a halt during the last ten - perhaps due to the brief reopening and/or lack of surveillance. It is interesting to note that $2 \mathrm{~m}^{3}$ reefs obtained the same results as regards density as the complexified Bonna reefs. The good performance of $2 \mathrm{~m}^{3}$ reefs has already been highlighted (CHARBONNEL et al., 2000). It would be advantageous to deploy such reefs as a way to sustain fisheries.

Further, the results of SIMPER analysis revealed great dissimilarities in the species composition as between empty and complexified Bonna reefs, and between empty Bonna reefs and the natural area. In each of the three years one or two species of Sparidae, Diplodus sargus and D. vulgaris were among those which most contributed to the differences observed. These species are generally the first to colonise artificial reefs (LEITAO et al., 2009).

The haphazardly chaotic heaps of around $100 \mathrm{~m}^{3}$ built with 1 and $2 \mathrm{~m}^{3}$ reef units are more attractive to fish than are the empty Bonna reefs (BARNABE et al., 2000). The great heterogeneity of a reef and the heterogeneity of the reef complexes appear to be the most important factors: (i) in increasing food resources for fish, (ii) in multiplying refuges of different sizes for young and adult fish and (iii) in increasing the diversity of the assemblage (HARMELIN; BELLAN-SANTINI, 1997). The design of reefs is a crucial factor that conditions their effectiveness (CHARBONNEL et al., 2000). A minimum of $400 \mathrm{~m}^{3}$ is recommended for fishery purposes as is an artificial reef bulk volume of about $3000 \mathrm{~m}^{3} / \mathrm{km}^{2}$ to ensure peak fish harvests (JAN et al., 2003). In our case, an average $16000 \mathrm{~m}^{3} / \mathrm{km}^{2}$ were deployed on the floor of the MPA studied. Species richness attained natural values only on the $2 \mathrm{~m}^{3}$ units. Fish density results though reduced were still good for $2 \mathrm{~m}^{3}$ and complexified Bonna reefs. 
Low connectivity between artificial reefs and shallow areas limited fish recruitment (no juvenile was observed during any of the censuses, data not given). In addition, the absence of surveillance and the waiving of restrictions opened the way for poaching. As a result, more than 25 years after the deployment of the artificial reefs, the density of the fish assemblages within this MPA did not show the expected increase sufficient to sustain local fisheries, even on the $2 \mathrm{~m}^{3}$ reefs, the most efficient in Golfe-Juan, and which permitted an increase in fish assemblage density.

Denny and Babcock (2004) highlighted that partially protected reserves are ineffective as conservation fishing tools for heavily targeted species or for fish communities. Marine reserves in which surveillance is exercised show the most ecologically significant responses (e.g. HARMELIN et al., 1995; FRANCOUR et al., 2001; GUIDETTI et al., 2008). The need to protect MPAs effectively with surveillance sufficient to limit or stop illegal fishing and an absence of temporal reopening (waiving of restrictions ?) seem to be obvious conditions to permit the sufficient increase of fishery resources where artificial reefs have been deployed to sustain local fisheries.

\section{ACKNOWLEDGMENTS}

This study was funded by the Conseil Général of the Alpes-Maritimes and we would like to thank Christophe Serre for his support. For the last census in 2008, we are indebted to Eric Dombrowski for his participation in the data collection and to François Giliberti (Nautile Diving Club), Jérémy Pastor and Jean-Michel Cottalorda (ECOMERS) for their help during the diving operations.

\section{REFERENCES}

ANDERSON, M. J.; GORLEY, R. N. PERMANOVA+ for PRIMER: Guide to software and statistical methods. Plymouth: PRIMER-E, 2007.

BARNABE, G.; CHARBONNEL, E.; MARINARO, J. Y.; ODY D.; FRANCOUR, P. Artificial reefs in France: analysis, assessments and prospects. In: JENSEN A.C.; COLLINS K.J.; LOCKWOOD A.P.M. (Ed.). Artificial reefs in European Seas. London: Kluwer Academic Publishers, 2000. p. 167-184.

BAYLE-SEMPERE, J. T.; RAMOS-ESPLA, A.; GARCIACHARTON, J. A. Intra-annual variability of an artificial reef fish assemblage in the marine reserve of Tabarca (Alicante, Spain, SW Mediterranean). Bull. mar. Sci., v. 55, n.2, p. 824-835, 1994.
BOMBACE, G.; FABI G.; FIORENTINI, L.; SPERANZA, S. Analysis of the efficacy of artificial reefs located in five different areas of the Adriatic Sea. Bull. mar. Sci., v. 555, p. 559-580, 1994.

BOHNSACK, J. A. Are high densities of fishes at artificial reefs the results of habitat limitation or behavioral preference? Bull. mar. Sci., v. 44, p. 631-645, 1989.

BORTONE, S.A.; SAMOILYS, M.A.; FRANCOUR, P. Fish and macroinvertebrate evaluation methods. In: Artificial reef evaluation with application to natural habitats, Boca Raton, Fla.: CRC Press, p. 127-164, 2000.

BRANDEN, K. L.; POLLARD, D. A.; REIMERS, H. A. A review of recent artificial reef developments in Australia. Bull. mar. Sci., v. 55, p. 982-994, 1994.

BRICKHILL, M. J.; LEE, S. Y; CONNOLLY, R. M. Fishes associated with artificial reefs: attributing changes to attraction or production using novel approaches. J. Fish Biol., v. 67, Suppl. B, p. 53-71, 2005.

CHARBONNEL, E. Les peuplements ichtyologiques des récifs artificiels dans le département des AlpesMaritimes (France). Bull. Soc. Zool. Fr., v. 115, n. 1, p. 123-136, 1990.

CHARBONNEL, E.; FRANCOUR, P. Etude de l'ichtyofaune des récifs artificiels du Parc Régional Marin de la Côte Bleue en 1993. Report. Marseille, France: GIS Posidonie Publisher, 1994. 66 p.

CHARBONNEL, E.; SERRE, C. Suivi des peuplements ichtyologiques des récifs artificiels de la zone marine protégée de Vallauris-Golfe-Juan (Alpes-Maritimes). Comparaison entre les périodes 1987/89 et 1997/98. Contrat Conseil Général des Alpes-Maritimes et GIS Posidonie. Marseille, France: GIS Posidonie Publ., 1999. p. 1-97.

CHARBONNEL, E.; FRANCOUR, P; HARMELIN, J. G. Finfish population assessment techniques on artificial reefs: a review in the European Union. In: JENSEN, A.C., (Ed.). European artificial reefs research. EARRN CONFERENCE, $1^{\text {st }}$, March 1996, Ancona, Italy. Proceedings... Southampton: Oceanography Centre Publisher, 1997. p. 261-277.

CHARBONNEL, E.; FRANCOUR, P.; HARMELIN, J. G.; ODY, D.; BACHET, F. Effects of artificial reef design on associated fish assemblages in the Côte Bleue Marine Park (Mediterranean Sea, France). In: JENSEN A.C.; COLLINS K. J.; LOCKWOOD A. P. M. (Ed. ). Artificial reefs in European Seas. London: Kluwer Academic Publishers, 2000. p. 365-377.

CHARBONNEL, E.; SERRE, C.; RUITTON, S.; HARMELIN, J. G.; JENSEN, A. Effects of increased habitat complexity on fish assemblages associated with large artificial reef units (French Mediterranean coast). ICES J. mar. Sci., v. 59, p. S208-S213, 2002.

CLARK, K. R.; WARWICK, R. M. Change in marine communities: an approach to statistical analysis and interpretation. $2^{\text {nd }}$ edition. Plymouth: PRIMER-E, 2001.

DENNY, C. M.; BABCOCK, R. C. Do partial marine reserves protect reef fish assemblages? Biol. Conserv., v. 116, p. 119-129., 2004.

FRANCOUR, P.; NIERI M.; URSCHELER, F. Les structures anti-chalut du Golfe de Beauduc (Camargue). Contrat Conseil Régional PACA, ADER PACA et GIS Posidonie. Marseille, France: GIS Posidonie Publ., 1991. 42 p. 
FRANCOUR, P.; HARMELIN, J. G.; POLLARD, D. SARTORETTO, S. A review of marine protected areas in the northwestern Mediterranean region: sitting, usage, zonation and management. Aquatic Conserv. Mar. Freshw. Ecosyst., v. 11, p. 155-188, 2001.

GOMEZ-BUCKLEY, M.C.; HAROUN, R.J. Artificial reefs in the Spanish coastal zone. Bull. mar. Sci., v. 55, n. 2-3, 1994.

GUIDETTI, P.; MILAZZO, M.; BUSSOTTI, S; MOLINARI, A.; MURENU, M.; PAIS, A.; SPANO, N.; BALZANO, R.; AGARDY, T.; BOERO, F.; CARRADAU, G.; CATTANEO-VIETTI, R.; CAU, A.; CHEMELLO, R.; GRECO, S.; MANGANARO, A.; NOTARBARTOLO DI SCIARA, G.; FULVIO RUSSO, G.; TUNESI, L. Italian marine reserve effectiveness: Does enforcement matter? Biol. Conserv., v. 141, p. 699-709, 2008

HARMELIN, J. G. Structure et variabilité de l'ichtyofaune d'une zone rocheuse protégée en Méditerranée (Parc National de Port-Cros, France). P.S.Z.N.I. Mar. Ecol., v. 8 , n. 3 , p. $263-284,1987$.

HARMELIN, J G.; BACHET, F; GARCIA, F. Mediterranean marine reserves: fish indices as tests of protection efficiency. Mar. Ecol., v. 16, n. 3, p. 233-250, 1995.

HARMELIN, J. G.; BELLAN-SANTINI, D. Assessment of biomass and production of artificial reef communities. In: EARRN CONFERENCE, $1^{\text {st, }}$ March, 1996, Ancona, Italy. Proceedings... Southampton: Oceanography Centre Publisher, 1997. p. 305-322,

JAN, R. Q.; LIU, Y. H.; CHEN, C. Y.; WANG, M. C.; SONG, G. S.; LIN, H. C.; SHAO, K. T. Effects of pile size of artificial reefs on the standing stocks of fishes. Fish. Res., v. 63, p. 327-337, 2003.

JENSEN, A.C.; COLLINS, K.J. The Poole Bay artificial reef project 1989 to 1994. Biol. Mar. Mediterr., v.2, n.1, p. 111-112, 1995.

JENSEN, A. C.; WICKINS. J.; BANISTER, C. The potential use of artificial reefs to enhance lobster habitats. In: JENSEN A. C., COLLINS K. J.; LOCKWOOD A. P. M. (Ed). Artificial reefs in European Seas. London: Kluwer Academic Publishers, 2000. p. 379-401.

LEITAO, F.; SANTOS, M.N.; ERZINI, K.; MONTEIRO, C.C. Diplodus spp. assemblages on artificial reefs: importance of near shore fisheries. Fish. Mgmt Ecol. n.16, p. 88-99, 2009.

LÖK, A.; METIN, C.; ULAS, A.; DÜZBASTILAR, F. O.; TOKAC, A. Artificial reefs in Turkey. ICES J. mar. Sci., v. 59, p. S192-S195, 2002.

MEINESZ, A.; BOUDOURESQUE, C. F.; JEUDY DE GRISSAC, A.; LAMARRE, F.; LEFEVRE, J. R.; MANCHE, A. Aménagements et préservations du milieu marin littoral en région Provence-Alpes-Côte d'Azur: bilans et perspectives.In: COLLOQUE SCIENTIFIQUE FRANCO-JAPONAIS D'OCÉANOGRAPHIE, v. 4, n. 6, p. 133-142, 1985.
MORENO, I. Effects of substrate on the artificial reef fish assemblage in Santa Eulalia Bay (Ibiza, Western Mediterranean). ICES J. mar. Sci., v. 59, p. S144-S149, 2002.

ODY, D; HARMELIN, J. G. Effects of the design and location of artificial reefs on Mediterranean fish assemblages. Cybium, v.18, n. 1, p. 57-70, 1994.

OSENBERG, C. W.; ST. MARY, C. M.; WILSON, J. A.; LINDBERG, W.J.. A quantitative framework to evaluate the attraction-production controversy. ICES J. mar. Sci., v. 59, p. S214-S221, 2002.

POLOVINA, J. J.; SAKAI, I. Impacts of artificial reefs on fishery production in Shimanaki, Japan. ICES J. mar. Sci., v. 44, p. 997-1003, 1989.

RAMOS-ESPLA, A. A.; GUILLEN, J. E., BAYLE, J. T.; SANCHEZ-PEREZ, P. Artificial anti-trawling reefs off Alicante, South-Eastern Iberian Peninsula: Evolution of reef block and set designs. In: JENSEN A.C., COLLINS K.J.; LOCKWOOD A.P.M. (Ed). Artificial reefs in European Seas. London: Kluwer Academic Publishers, 2000. p. 195-218.

REED, D. C.; SCHROETER, S. C.; HUANG, D.; ANDERSON, T. W.; AMBROSE, R.F. Quantitative assessment of different artificial reef designs in mitigating losses to kelp forest fishes. Bull. mar. Sci., v. 78, n. 1, p. 133-150, 2006.

RELINI, G.; RELINI, M.; PALANDRI, S.; PALANDRI, G.; MERELLO, S.; BECORNIA, E. History, ecology and trends for artificial reefs of the Ligurian sea, Italy. Hydrobiologia, v. 580, p. 193-217, 2007.

SANTAELLA, E.; REVENGA, S. Artificial reefs and marine reserves. Implementation of the objectives from multiannual guidance programmes 1987-1991 and 19921996. Boll. Oceanol. teor. appl., v. 11, n. 3-4, p. 165$172,1995$.

SANTOS, M. N.; MONTEIRO, C. C. A fourteen year overview of the fish assemblages and yield of the two oldest Algarve artificial reefs in Portugal (southern Portugal). Hydrobiologia, v. 580, p. 225-231, 2007.

SEAMAN, W.; JENSEN, A. C. Purposes and practices of artificial reef evaluation. In: SEAMAN, W. (Ed.). Artificial reef evaluation with application to natural marine habitats. Boca Raton, Fla.: CRC Press, 2000. p. 1-19.

SIMARD, F. Réflexions sur les récifs artificiels au Japon. Biol. Mar. Mediterr., v. 2, n. 1, p. 99-109 1995.

(Manuscript received 18 February 2011; revised 26 June 2011; accepted 04 June 2011) 